\title{
Factors Influencing Choice of Occupational Area among Technical Education Students with Differing Entry Qualifications
}

\author{
Japo Oweikeye Morto Amasuomo ${ }^{1}$ \\ ${ }^{1}$ Niger Delta University [E-mail: japoamasuomo@gmail.com]
}

\begin{abstract}
This study investigated the factors that influenced choice of occupational area of two groups of students admitted into the Nigeria Certificate in Education (NCE) Technical Programme who had Senior Secondary School Certificate (SSSC) and National Technical Certificate (NTC) respectively. Third year Technical Education students of the Federal College of Education (Technical), Omoku, Nigeria comprising 40 and 30 students with SSSC and NTC respectively were used for the study. Arithmetic mean and t-test were used to analyse the data. Reliability of the t-test results was ascertained by the use of ftest of homogeneity of group variance. Interest in study area; perceived availability of job opportunities related to area of specialization; simplicity of area in training and in employment; and perceived affordability of equipment for self-employment were found to influence choice of occupational area among the two groups.
\end{abstract}

Keywords: Technical Education; Career guidance; TBVET; Entry qualification.

\section{$1 \quad$ Introduction}

In Nigeria, two groups of students with different but equivalent entry qualifications are admitted into the NCE Technical Programme. The two groups of student are those with either the Senior Secondary School Certificate (SSSC) or the National Technical Certificate (NTC). The SSSC is awarded by either the West African Examination Council (WAEC) or the National Examination Council (NECO) to students who passed and graduated from the secondary schools. This certificate is equivalent to the Ordinary Level (O'Level) Certificate. The NTC is awarded by the National Business and Technical Examination Board (NABTEB) to students who passed and graduated from the technical colleges or the science and technical colleges. 
This certificate is equivalent to the London City and Guilds Intermediate Certificate.

The Nigeria Certificate in Education (NCE) Technical programme is a three years postsecondary training offered in the colleges of education aimed at producing technical teachers with the intellectual and professional background adequate for teaching technical subjects and to make then adaptable to any changing situation in technological development not only in the country but also in the world at large (NCCE, 2008). Therefore, students admitted into NCE Technical Programme offer all the courses listed in the first and second years to acquire knowledge of Basic Technology components to enable them teach Basic Technology either in Junior Secondary Schools or Junior Technical Colleges before they are allowed to choose an occupational area in the third year to enable them fit into an industry based on the training acquired in the NCE technical programme. Also choice of occupational area in third year is based on performance of the student in the related courses leading to the occupational area. It is in realization of this that, the National Commission for Colleges of Education (NCCE) stipulated that every student for the NCE Technical Programme will offer all the courses listed in the first and second years of the programme before choosing an area of specialization in the third year (NCCE, 2008). The areas of specialization are automobile, building, electrical/electronics, metalwork and woodwork technology education respectively. These areas of specialization also form the student's occupational areas.

This study attempts to investigate the factors that could influence the choice of occupational area in third year of the NCE Technical Education students with different entry qualification.

\section{$2 \quad$ Literature Review}

With the increasing diversity in a complex world of technology and work; the variety of occupational paths offered for a young person has also increased and become complex. It is therefore pertinent for students to obtain necessary information in occupational areas and acquire the necessary skills to be successful in the future occupational plans. Any individual making a decision in occupational choice is influenced not by their development but also by the context in which they live, their personal attitudes and educational attainment (Chen, 1997; Bandura, Barbaranelli, Caparara \& Pastorelli, 2001). For an adolescent who has graduated from post primary school, the major turning point in his or her life involves the occupational choice they will make in their post-secondary school training. These career selections according to Borchert 
(2002) is one major important choices students will make in determining future plans and this decision will impart them throughout their lives.

Studies carried out on some of the factors that influence occupation choices include: parents and family, teachers and counsellors as well as the media such as newspapers, television etc. (Eccles, 1997; Epstein, 1992; Haverman \& Wolfe, 1995; Windham, 1996; Howe, 1997; Davies, Spencer \& Steele, 2005; Walton \& Cohen, 2007. Thus, occupational decisions taken by young people is therefore a combination of both personal (those originating within the individual) and situational factors (forces enabled from social context) (Amani, 2013). The personal factors are those that include cognitive and mental processes which dictate career decision making such as attitude, self-concept, self-efficacy and knowledge (Sharf, 1992). The situational or environmental factors which include social or external factors from the society may influence ones career decisions. These social pressures which are valuable to the students may come from parents, relatives, teachers, friends, peers and the society in general which partly determines the decision of a person whether to join a career or not (Amani, 2013). In addition, the interdependency of family, school and community culture plays a critical role in shaping the youth's occupational choice. The young adults through interaction with the context of family, school and community learn about and explore careers that ultimately lead to career choice. The economic and social circumstances of the broader community colours and influences the youth's perception of appropriate career choices (Ferry, 2006).

Personality also has an important role in influencing student's occupational choice because some careers demand that you have the personality to match the qualities of the occupation (Borchert, 2002). Splaver (1997) was also of the view that personality plays an important role in the choice of right career. Thus, a student's personality must be a self-motivated type so as to investigate career possibilities from early in their lives and not the procrastinating type that will wait until they are compelled to decide. In essence, it is important for you to have a good understanding of yourself and your personality if you are to make intelligent career plans.

However, factors considered in this study as influencing students' choice of occupational areas are: interest, parental desires, future job opportunity, understanding the related courses in the occupational area, availability of adequately equipped workshops and laboratories, teachers instructional methods and competency, peer group influence, high social status attached to the occupational area, occupational area is less tedious during training and also during employment, information on career prospects, finance to procure equipment and tools for self-employment, previous background knowledge of occupational area, and the imposition of occupational area based on student's performance. 
A student's personal interest in an occupational area is very important in occupational choice. Many students try to fit in a course based purely on personal interest (Reynolds, 2013). Davison (2003) and Amani (2013) also reported that among the several deciding factors in choosing a career was selfinterest in the department within the academic environment and this was the major factor which influenced student's choice of degree programmes. Therefore, for students to choose an occupation there must be interest for such student to derive job satisfaction in the future (Olayinka, 1983; Giachino \& Gallington, 1977).

The parent's desire for a child to choose a particular occupation influences students' choice of occupation. In this regard, Agarwala, (2008); Hines, (1997); Lee, (1984); Leong, (1995) reported that parents especially the father and other family members were the most influential determinant of their children's career choice intentions, occupational aspirations and occupational expectations. Thus, even if schools had resources with which to meet young people's career guidance needs, neither the teachers nor the counsellors can replace the influence parents have on their sons and daughters' career plans because the parent's career aspirations aid children in selecting occupational goals, influence their knowledge of occupations and familiarize them with occupational roles and requirements (Otto, 1989). And whether the child internalizes those aspirations is greatly determined by numerous values found within the home. That is, the occupational orientations of the parents familiarize children with occupational roles, while the value orientations of parents provide the learning environment that motivates the aspirations of the children (Hairston, 2000; Lee, 1984). In addition, parents were found to have key roles in shaping career choices of their children through educational expectations and perceptions of occupational opportunities as well as providing early exposure to vocational matters thereby aiding in the discovery of aptitudes related to vocational subjects (Ferry, 2006; Hairston, 2000).

Role models and the intervention of relations can also influence students in choosing an occupation. A role model a student saw on television or a lecturer, professor or a relation can be the role model that influences a student's occupational choice (Borchert, 2002; Amani, 2013; Akinjide \& Sehinde, 2011).

Students also choose occupational areas where they are sure of possible future job opportunity. Borchert (2002) stated that job opportunity is another factor that may shape career choices for students which may also influence how they have perceived their future in terms of the reasonable probability of a better future in a particular career field. Ferry (2006) also posited that occupational choice is not a mere matching process but it is a choice made in a context of many influencing factors. The perception of ideal job acts as a filter for appropriateness and this in turn influences the choice process. 
In addition, students choose occupational area while in training because the related courses leading to the occupational area are easier to understand (Reynolds, 2013). Further, students prefer to choose occupational areas from departments with adequately equipped workshops and laboratories for effective practical training as against only theory because proper skill training is very important in future occupational engagements. According to Taiwo (1974), the workshop and farm enriches general education and the experience a student gets in the school workshop is what the student utilizes in the related industries after graduation.

Another factor that may influence student's choice of occupational area is the teacher's instructional methods and competency. Competency is the ability to do something well when measured against a standard. It is the ability acquired through experience and training. Therefore, it is not unusual for students to try to get into a course because of the reputation of the professor teaching it. This may be because of an outstanding performance of the professor in his/her field or because the professor is regarded as a fine teacher (Reynolds, 2013). The competence of the teacher in influencing the student's choice of occupational area becomes more pertinent since the teacher constitutes the single most important fabric upon which hangs the success of the whole educational edifice (Adesina, 1977).

Peer groups also influences students in choosing an occupational area. Friends and the mentoring relationship with a teacher in a particular discipline can foster a sense of social belonging which impacts on choice of area of specialization (Davison, 2013; Hall, Sullivan, Kauffman, Batts \& Long, 2009)

The high social status attached to some occupational areas influences students' choice. The choice of occupational area by a student is bound to be affected if low prestige is attached to the particular occupational area. Some occupations have social status and prestige attached to it and hence high esteem. For this reason, most young people scramble for them (Olayinka, 1983).

Students may not like to choose an occupational area that is tedious during training and thereafter during employment because they do have the stamina to withstand the rigours of such occupations. Most students would therefore prefer occupational areas that are less tedious during training and during employment (Amasuomo, 2000).

Availability of information on occupational prospects in most cases influences occupational choice by students. Occupational information helps students to have a self-evaluation of their characteristics, preferences and capabilities (Barango-Tariah, 1999). Further, encouragement from teachers and information from someone at the school level that was knowledgeable about different career options can influence students to consider various career options (Hall, Sullivan, Kauffman, Batts \& Long, 2009). 
The amount of capital required to establish workshops for self-employment may also influence student's choice of occupational area. One of the objectives of technical education is for the recipients to be self-employed after training (NCCE, 2008). Students may not choose some occupations which require huge amount of money to establish workshops for self-employment.

Previous background knowledge of the occupational area to a large extent influences the choice of occupational area. According to Amani, (2013), there was a positive relationship between occupational knowledge and intents of some students to join their careers upon graduation. While students who come into occupational training from the secondary schools may not have previous knowledge of the occupational area they are choosing but students from the technical and vocational colleges already have an occupational path and therefore are work-bound. The occupational goals of work-bound youths are identified because they already know what they are going to do when they get out to choosing a major for training. Thus, the choice of occupational area for those students at the post-secondary level is more direct. Their choice of occupational area is less influenced by extraneous factors since their occupational objectives and plans are already put in place and the choice of an occupational area has already been made. The students from the secondary schools who do not have previous occupational knowledge have career trajectories that are future oriented and are only exposed to occupation choice at the post-secondary school level (Ferry, 2006).

Academic performance of a student may also influence the student's choice of occupational area in situations where the choice is dependent on performance in the related courses that lead to the occupational area. An above average performance in specific related courses may therefore be required for a student to be allowed to choose an occupational area. In cases like this, an occupational area may be imposed on the student irrespective of the interest of the student in a particular occupational area since the student did not perform better in the area of interest. According to Gesinde (1986), these category of students were forced by circumstances influenced by a powerful stimulus.

Previous studies indicated that various factors influenced students' choice of occupational areas. It became pertinent to find out whether theses factor that influenced occupational choices will differ among students with different entry qualifications. Specifically, the study shall find answers to the following research questions:

1. What are the factors that influence occupation choice among students with different entry qualifications?

2. Will the factors that influence occupation choice among students with different entry qualifications differ? 
A null hypothesis using the second research question was formulated thus: There will be no statistically significant difference in the factors that influence occupation choice among students with different entry qualifications

\section{$3 \quad$ Methodology}

The study population was made up of seventy 300 Level NCE Technical Education students of the Federal College of Education (Technical), Omoku, Nigeria during the 2011/2012 academic session. The population which constituted the sample is comprised of forty and thirty students with Senior Secondary School certificates (SSSC) and National Technical Certificates (NTC) respectively.

The research instrument was a questionnaire containing thirteen (13) items that tried to elicit the factors that influence students' choice of occupational area in NCE Technical Education programme. The answer options were: High influence, Moderate influence and Low influence and were accordingly rated (3), (2) and (1) respectively on a three-point scale. The questionnaire was administered by the researcher and the students were given a week or the next lecture period to submit the completed questionnaire. The entire administered questionnaire was completed and personally retrieved by the researcher.

Data was analysed using arithmetic mean in the response scores categories. On a 3-point scale, mean responses above 2.00 indicated that the assessed factors influenced the students' choice of occupational areas while mean responses below 2.00 was an indication that the assessed factors did not influenced them. The Z-test of two independent groups' means was used to test for significance difference in the choice of occupational area among the two groups. The f-test of homogeneity of variance of both groups used the Hartley's F-Max test with the greater variance as numerator and smaller variance as denominator (Gravetter and Wallnau, 2005). The tests were two-tailed and conducted at the 0.05 level of significance

\section{$4 \quad$ Results}

The results presented in Table 1 revealed that interest, future job opportunity, the occupational area is less tedious during training and during employment; and finance to procure equipment and tools to set up workshop for selfemployment influenced both the SSSC and the NTC groups of students in choosing an occupational area. Parental desire, understanding the related courses leading to occupational area, availability of adequately equipped 
workshops and laboratories, high social status attached to the occupational area and information on occupational prospects only influenced the SSSC students in the choice of occupational area. Previous background knowledge of occupational area only influenced the NTC students. 
Makerere Journal of Higher Education

Table 1: Factors influencing students' choice of occupational area

\begin{tabular}{|c|c|c|c|c|c|c|c|c|c|c|c|c|}
\hline \multirow[t]{2}{*}{ Influencing factors } & \multicolumn{6}{|c|}{$\begin{array}{l}\text { Senior secondary school certificate } \\
\text { group }(n=40)\end{array}$} & \multicolumn{6}{|c|}{$\begin{array}{l}\text { National Technical certificate group } \\
(\mathrm{n}=30)\end{array}$} \\
\hline & $\mathrm{HI}$ & $\mathrm{MI}$ & $\mathrm{LI}$ & $x$ & SD & Decision & $\mathrm{HI}$ & MI & $\mathrm{LI}$ & $\mathrm{x}$ & SD & Decision \\
\hline Interest in occupational area & 35 & 2 & 3 & 2.80 & 0.61 & $\begin{array}{l}\text { There was } \\
\text { influence }\end{array}$ & 18 & 3 & 9 & 2.30 & 0.92 & $\begin{array}{l}\text { There was } \\
\text { influence }\end{array}$ \\
\hline Parental desire & 18 & 17 & 5 & 2.33 & 0.69 & $"$ & 8 & 4 & 18 & 1.67 & 0.88 & No influence \\
\hline Future job opportunity & 31 & 2 & 7 & 2.60 & 0.78 & $"$ & 15 & 6 & 9 & 2.20 & 0.89 & $\begin{array}{l}\text { There was } \\
\text { influence }\end{array}$ \\
\hline $\begin{array}{l}\text { Understanding the related courses leading } \\
\text { to occupational area }\end{array}$ & 19 & 9 & 12 & 2.18 & 0.87 & $"$ & 11 & 2 & 17 & 1.86 & 0.97 & No influence \\
\hline $\begin{array}{l}\text { Availability of adequately equipped } \\
\text { workshops and laboratories }\end{array}$ & 18 & 16 & 6 & 2.30 & 0.72 & $"$ & 6 & 12 & 12 & 1.80 & 0.76 & $"$ \\
\hline $\begin{array}{l}\text { Teacher's instructional methods and } \\
\text { competency }\end{array}$ & 15 & 2 & 23 & 1.75 & 0.97 & No influence & 5 & 14 & 11 & 1.80 & 0.76 & $"$ \\
\hline Peer Group Influence & 18 & 14 & 8 & 2.2 & 0.76 & $\begin{array}{l}\text { There was } \\
\text { influence }\end{array}$ & 5 & 15 & 10 & 1.83 & 0.70 & $"$ \\
\hline $\begin{array}{l}\text { High social status attached to the } \\
\text { occupational area }\end{array}$ & 22 & 13 & 5 & 2.43 & 0.71 & $"$ & 7 & 12 & 11 & 1.87 & 0.77 & $"$ \\
\hline $\begin{array}{l}\text { The occupational area is less tedious } \\
\text { during training and during employment }\end{array}$ & 19 & 14 & 7 & 2.30 & 0.76 & $"$ & 20 & 4 & 6 & 2.46 & 0.82 & $\begin{array}{l}\text { There was } \\
\text { influence }\end{array}$ \\
\hline Information on occupational prospects & 21 & 15 & 4 & 2.43 & 0.68 & $"$ & 6 & 14 & 10 & 1.87 & 0.73 & No influence \\
\hline $\begin{array}{l}\text { Finance to procure equipment and tools to } \\
\text { set up workshop for self-employment }\end{array}$ & 18 & 18 & 4 & 2.35 & 0.62 & $"$ & 16 & 12 & 3 & 2.50 & 0.69 & $\begin{array}{l}\text { There was } \\
\text { influence }\end{array}$ \\
\hline $\begin{array}{l}\text { Previous background knowledge of } \\
\text { occupational area }\end{array}$ & 17 & 1 & 22 & 1.88 & 0.99 & No influence & 13 & 9 & 8 & 2.15 & 0.92 & $"$ \\
\hline $\begin{array}{l}\text { Choice occupational area was imposed } \\
\text { because the student performed better in } \\
\text { that area }\end{array}$ & 6 & 0 & 34 & 1.30 & 0.72 & $"$ & 3 & 0 & 27 & 1.20 & 0.61 & $\begin{array}{l}\text { No } \\
\text { influence }\end{array}$ \\
\hline
\end{tabular}

$\mathrm{Df}=64 ; \mathrm{P}>=0.05$; Expected $\mathrm{t}$-Value =2.00; No. of SSSC Group $(\mathrm{N})=40$; No. of NTC Group $(\mathrm{N})=30 ; \mathrm{S}=$ Significant; NS = Not significant. 
J.O.M. Amasuomo: Choice of Occupational Area among Technical Education Students

Table 2: Z-test for significance of difference

\begin{tabular}{|c|c|c|c|c|c|}
\hline Assessed influencing factors & Entry qualification & Mean & SD & Z-value & \\
\hline \multirow{2}{*}{ Interest in occupational area } & SSSC group & 2.80 & 0.61 & 2.54 & $\mathrm{~S}$ \\
\hline & NTC group & 2.30 & 0.92 & & \\
\hline \multirow[t]{2}{*}{ Parental desire } & SSSC group & 2.33 & 0.69 & 3.35 & $S$ \\
\hline & NTC group & 1.67 & 0.88 & & \\
\hline \multirow[t]{2}{*}{ Future job opportunity } & SSSC group & 2.60 & 0.78 & 1.89 & NS \\
\hline & NTC group & 2.20 & 0.89 & & \\
\hline \multirow[t]{2}{*}{ Understanding the related courses leading to occupational area } & SSSC group & 2.18 & 0.87 & 1.45 & NS \\
\hline & NTC group & 1.86 & 0.97 & & \\
\hline \multirow[t]{2}{*}{ Availability of adequately equipped workshops and laboratories } & SSSC group & 2.30 & 0.72 & 2.75 & S \\
\hline & NTC group & 1.80 & 0.76 & & \\
\hline \multirow[t]{2}{*}{ Teacher's instructional methods and competency } & SSSC group & 1.75 & 0.97 & 0.23 & NS \\
\hline & NTC group & 1.80 & 0.76 & & \\
\hline \multirow[t]{2}{*}{ Peer group influence } & SSSC group & 2.20 & 0.76 & 2.08 & S \\
\hline & NTC group & 1.83 & 0.70 & & \\
\hline \multirow[t]{2}{*}{ High social status attached to the occupational area } & SSSC group & 2.43 & 0.71 & 2.90 & S \\
\hline & NTC group & 1.87 & 0.77 & & \\
\hline \multirow[t]{2}{*}{ The occupational area is less tedious during training \& in employment } & SSSC group & 2.30 & 0.76 & 0.82 & NS \\
\hline & NTC group & 2.46 & 0.82 & & \\
\hline \multirow[t]{2}{*}{ Information on occupational prospects } & SSSC group & 2.43 & 0.68 & 3.41 & S \\
\hline & NTC group & 1.87 & 0.73 & & \\
\hline \multirow{2}{*}{$\begin{array}{l}\text { Finance to procure equipment and tools to set up workshop for self- } \\
\text { employment }\end{array}$} & SSSC group & 2.35 & 0.62 & 0.43 & NS \\
\hline & NTC group & 2.50 & 0.69 & & \\
\hline \multirow[t]{2}{*}{ Previous background knowledge of occupational area } & SSSC group & 1.88 & 0.99 & 1.17 & NS \\
\hline & NTC group & 2.15 & 0.92 & & \\
\hline \multirow{2}{*}{$\begin{array}{l}\text { Choice occupational area was imposed because the student performed } \\
\text { better in that area }\end{array}$} & SSSC group & 1.30 & 0.72 & 0.6 & NS \\
\hline & NTC group & 1.20 & 0.64 & & \\
\hline
\end{tabular}


The Z-test results presented in Table 2 indicated that there was significant difference among the SSSC group and their NTC counterparts in the following assessed areas: interest, parental desire, availability of adequately equipped workshops and laboratories, peer group influence, high social status attached to the occupational area and information on occupational prospects. Hence the null hypothesis was rejected because the Z-test values for each of the influencing factors were more than the expected table value of 2.00 at $\mathrm{P}>=0.05$

However, there was no significant difference among the SSSC and the NTC groups in the following factors: future job opportunity, understanding the related courses leading to occupational areas, the teacher's instructional methods and competency, occupational area is less tedious during training and during employment, finance to procure equipment and tools to set up workshop for self-employment, previous background knowledge of occupational area and choice of occupational area was imposed because the student performed better in that area. Thus, the null hypothesis was accepted since the calculated Z-test values were less than the table value of 2.00 at $\mathrm{P}>=$ 0.05 . 
J.O.M. Amasuomo: Choice of Occupational Area among Technical Education Students

Table 3: Test of Homogeneity of Group variances

\begin{tabular}{|c|c|c|c|c|}
\hline Assessed influencing factors & Entry qualification & Mean & Variance $\left(\mathrm{S}^{2}\right)$ & f-value \\
\hline \multirow[t]{2}{*}{ Interest in occupational area } & SSSC group & 2.80 & 7.84 & 1.48 \\
\hline & NTC group & 2.30 & 5.29 & NS \\
\hline \multirow[t]{2}{*}{ Parental desire } & SSSC group & 2.33 & 5.43 & 0.97 \\
\hline & NTC group & 1.67 & 2.79 & NS \\
\hline \multirow[t]{2}{*}{ Future job opportunity } & SSSC group & 2.60 & 6.76 & 1.40 \\
\hline & NTC group & 2.20 & 4.84 & NS \\
\hline \multirow[t]{2}{*}{ Understanding the related courses leading to occupational area } & SSSC group & 2.18 & 4.75 & 1.37 \\
\hline & NTC group & 1.23 & 3.46 & NS \\
\hline \multirow[t]{2}{*}{ Availability of adequately equipped workshops and laboratories } & SSSC group & 2.30 & 5.29 & 1.63 \\
\hline & NTC group & 1.80 & 3.24 & NS \\
\hline \multirow[t]{2}{*}{ Teacher's instructional methods and competency } & SSSC group & 1.85 & 3.42 & 1.06 \\
\hline & NTC group & 1.80 & 3.24 & NS \\
\hline \multirow[t]{2}{*}{ Peer group influence } & SSSC group & 2.20 & 4.93 & 1.47 \\
\hline & NTC group & 1.83 & 3.35 & NS \\
\hline \multirow[t]{2}{*}{ High social status attached to the occupational area } & SSSC group & 2.40 & 5.90 & 1.69 \\
\hline & NTC group & 1.87 & 3.50 & NS \\
\hline \multirow{4}{*}{$\begin{array}{l}\text { Occupational area is less tedious during training and during } \\
\text { employment } \\
\text { Information on occupational prospects }\end{array}$} & SSSC group & 2.30 & 5.29 & 1.14 \\
\hline & NTC group & 2.46 & 6.05 & NS \\
\hline & SSSC group & 2.43 & 5.90 & 1.69 \\
\hline & NTC group & 1.87 & 3.50 & NS \\
\hline \multirow{4}{*}{$\begin{array}{l}\text { Finance to procure equipment and tools to set up workshop for self- } \\
\text { employment } \\
\text { Previous background knowledge of occupational area }\end{array}$} & SSSC group & 3.34 & 5.52 & 1.13 \\
\hline & NTC group & 2.50 & 6.25 & NS \\
\hline & SSSC group & 1.88 & 3.53 & 1.31 \\
\hline & NTC group & 2.15 & 4.62 & NS \\
\hline \multirow{2}{*}{$\begin{array}{l}\text { Choice occupational area was imposed because the students' } \\
\text { performed better in that area }\end{array}$} & SSSC group & 1.30 & 1.69 & 1.17 \\
\hline & NTC group & 1.20 & 1.44 & NS \\
\hline
\end{tabular}
performed better in that area NTC group 1.20 
The results of the f-tests presented in Table 3 revealed that, the calculated fvalue of the factors that influenced students' choice of occupational areas was less than the expected table value of 1.84. Based on this result, the variance of the SSSC and the NTC groups in each of the assessed influencing factors were not different, and the homogeneity assumption of the variances of both groups was therefore valid. Thus, the calculated Z-values were reliable.

\section{$5 \quad$ Discussion and Conclusion}

In determining the factors that influenced students' choice of occupational areas, interest in the occupational area influenced senior secondary school certificate (SSSC) and National Technical Certificate (NTC) groups of students in choosing an occupational area. This finding was consistent with David (2003); Amani (2013); Olayinka (1983); Giachino and Gallington (1977) who reported that before a student will choose an occupation, there must be selfinterest in the occupational area for such student to derive job satisfaction in the future. Thus a student's personal interest in an occupational area is very important in occupational choice.

Parental desire for the occupational area influenced only the SSSC students. In this regard Parham and Austin (1994); Otto (1989) also observed that family members particularly parents are the most influential determinant of career plans, occupational aspirations and occupational expectations. The findings also agreed with Ferry (2006); (Hairston, 2000) who stated that through educational expectations and perceptions of occupational opportunities, parents were found to have key roles in shaping career choices by aiding in the discovery of aptitudes related to vocational subjects and students' decision to prepare for a career. Therefore, parental influence on students' choice of occupational area will be very strong, especially where most parents would want their children to pursue a particular profession for the sake of prestige or they may want children who will step into their professions when they grow old (Olayinka, 1983, Gesinde, 1986). The influence of parents and relations or role models to a great extent therefore influenced the child's preferences in the choice of career. However, the NTC group of students were not influenced by parental desires. This could be attributed to the fact that such students already had a certificate in a vocational area at the post primary school level from a technical college. Therefore, they could not have chosen any other profession apart from the one they know best. Further, education was only an avenue to enhance their status in the job place.

Job opportunity influenced both groups of students in the choice of occupational area. This implies that, after the NCE Technical Programme, there 
is an assurance of a better job in the future, high income, social influence, improved condition of living and advancement in the job place (Olayinka 1983, Okon 1986 and Gesinde 1986). Borchert, (2002); Davison (2013); Ferry (2006) also concurred that job opportunity influenced how students have perceived their future in terms of the reasonable probability of a future in a particular career field and that occupational choice was not a mere matching process but it is a choice made in a context of many influencing factors. Thus, no student would want to choose an occupational area that is not assured of quick and good employment. Also no parent would want to spend huge amounts of money in training a child in occupational areas that do not have job opportunities. Okon (1986) also reported that it is a fact that young people and their parents do not want education principally as an end in itself but as a means of getting better employment and improved condition of living.

The ability of the student to understand the related courses that are listed in the first and second year of the programme influenced the SSSC students in the choice of occupational area. This means that interest, parental influence and job opportunity alone are not the only criteria for choosing a carrier, but the necessary aptitude for the courses that may lead to that occupational area is also required (Olayinka 1983, Gianchino, Gallington 1977 and Miller 1985). However, this factor did not influence NTC students since the curricula for the NCE Technical Education programme were like the vocational training at the post primary level. It was only enlarged and more elaborate in nature and the training the students get at the NCE Technical Education programme is a continuation of vocational training at the post primary level.

The availability of adequately equipped workshops and laboratories influenced the choice of occupational area of the SSSC students. That is, adequately equipped workshops and laboratories for effective skill training was very important for them in their future occupational engagements. According to Taiwo (1974), the workshop and farm enriches general education and the experience a student gets in the school workshop is what the student utilizes in the related industries after graduation. However, this factor did not influence the NTC students. The reason was that they already had an occupational path at the post primary vocational level. Further vocational training at the postsecondary level was only to improve their skills and enter into the job market at a high level with more responsibilities and higher salary.

The teachers' instructional methods and competency did not influence any of the two groups of students in choice of occupational area. The implication was that the various departments had adequate supply of qualified and competent teachers. Therefore, the students do not have any reason to change occupational area in their third year after the transition period of the occupational training. The few students who had contrary opinion may have done so because a 
particular teacher was a fine and outstanding instructor in the field through the acquisition of experience and training (Reynolds, 2013.)

The SSSC students were mostly influenced by peer groups in the choice of occupational areas. The impact of peer group influence on students' choice of occupational area was very strong. The peer group influence is likely to occur in the NCE Technical programme because no student specializes in an occupational area in their first and second years of the training programme. Therefore, the two years in-between before a student chooses an occupational area in the third year is enough time for the student to change occupational areas different from the one he/she originally intended especially where they could not withstand the peer group pressure. Davison (2013); Hall, Sullivan, Kauffman, Batts \& Long (2009) therefore reported that friends were the most influential in the choice of area of specialization. The peer group factor did not influence the NTC group of students. The simple reason was that whatever peer group influence they had was in the post primary vocational training. The NTC group of students already had an occupational path to follow from the training they had in their post primary vocational training in the technical colleges.

The social status attached to an occupational area influenced choice of occupational area among the SSSC students. This report agreed with Olayinka, (1983) who reported that social status and prestige attached to the career such as the type of esteem for the workers demand careers and other prospects for social influence and advancement. For this reason most young people scramble for occupational areas with high social status and prestige. For the NTC students, the social status attached to the occupational area did not influence their occupational choice at the NCE Technical training programme because occupational choice has already been made at post primary vocational level.

Most students were influenced in their choice of occupational areas because such occupations were less tedious during training and also during their working life. Therefore, students who do not have the required stamina to persevere in such occupational area may not want to choose such occupations (Amasuomo, 1996).

Information on occupational prospects influenced most students to choose occupational areas among the SSSC group of students. In this regard (BarangoTariah, 1999; Hall, Sullivan, Kauffman, Batts \& Long (2009) opined that students make occupational choices based on their self-evaluation in terms of their own characteristics, preferences and capabilities. This also involves information on career and occupation, characteristics of range of jobs, risks of future unemployment and job. Information on occupational prospects did not influence the NTC students in choice of occupational area. This group of students had chosen occupational areas in their vocational trainings at the post primary school levels. 
The SSSC and NTC students all agreed that finance to procure equipment and tools to set up workshops for self-employment influenced their choice of occupational areas. It will be a frustrating exercise for an NCE technical student who after acquiring training in an occupational area later discovered that the chosen occupational area requires large amount of capital to be self-employed. Where this happens, the objectives of the NCE Technical Education programme where graduates are also expected to be self-employed in the occupational area after training (NCCE, 2008) will not be achieved.

Previous background knowledge of the occupational area only influenced the NTC group of students in occupational choice. This is because the curriculum of such students was tailored towards a vocation at the technical school level. In the same vein Amani, (2013) posited that there was a positive relationship between occupational knowledge and intents of some students to join their careers upon graduation. The students from the technical and vocational colleges already have an occupational path and therefore are work-bound. Their choice of occupational area is less influence by extraneous factors since their occupational objectives and plans are already put in place. However, this factor did not influence the SSSC students since their curriculum was general. These students were only exposed to occupational choice at the post-secondary school level. Therefore, factors such as parental, peer group, the teacher, interest, future job opportunities, social status of the occupation, etc. could influence them in their choice of occupational area.

The two groups of students were of the opinion that imposition of the occupational area did not influence their choice of occupational area. There were few cases where students' choice of occupational area was dependent on performance of the student in the related courses that led to the occupational area. In cases like this, an occupational area may be imposed on the student irrespective of the interest of the student in a particular area. The finding was consistent with Gesinde (1986) who observed that this category of students are likened to an individual who did not deliberately plan to enter into any particular job, rather circumstances forced it on the individual, and he only succumbed to the influence of a powerful stimulus.

It was concluded from the findings that factors such as interest in occupational area, future job opportunity, the occupational area is less tedious during training and during employment, finance to procure equipment/tools to set up workshop for self-employment influenced the choice of occupational areas among students in the NCE Technical programme whose entry certificates were different. Other factors such as parental desire, understanding the related courses leading to occupational area, availability of adequately equipped workshops/laboratories and previous background knowledge of occupational area that individually and severally influenced the two groups of 
students in the choice of occupational area sometimes varied. Further, whether any significant difference existed or not in the extent of influence of the assessed factors among the senior secondary school certificate and the National Technical certificate students in their choice of occupational area also varied.

\section{References}

Adesina, S. (1977). Planning and educational development. Yaba, Lagos Educational Industries Ltd.

Agarwala, T. (2008). Factors influencing career choice of management students in India. Career Development International, 13 (4), 362-376.

Akinjide, G. A., \& Sehinde, A. (2011). Teacher characteristics and students' career choice of teaching as career in Osun State. Edo Journal of Counselling, 4(1), 116-129

Amani, J. (2013). Social influence and occupational knowledge as predictors of career choice intentions among undergraduate students in Tanzania. International Journal of Learning \& Development 3(3), 185-193. Retrieved on December 5, 2013 from www.macrothink.org/ijld185

Bandura, A., Barbaranelli, C., Caprara, G. V., \&Pastorelli, C (2001). Self efficacy beliefs as shapers of children's aspirations and career trajectories, Child Development, 72,187-201.

Barango-Tariah, S. B. (1999). Management of directed work experienceLecture notes. Department of Science and Technical Education, Rivers State University of Science and Technology, Port Harcourt, Nigeria

Borchert, M. (2000). Career Choice Factors of High School Students, Master of Science Degree research paper, The Graduate College University of Wisconsin-Stout. Retrieved on December 12, 2013 from http://www2.uwstout.edu/content/lib/thesis/2002/2002borchertm.pdf

Chen, C. P. (1997). Career projection: Narrative in context. Journal of Vocational Behaviour, 54, 279-295.

Davison, J. (2013). Factors promoting increased student enrolment in the communication and leadership development specialization of University of Florida's agricultural education and communication major. Retrieved on December 5, 2013 from http://www.honors.ufl.edu/apps/Thesis.aspx/Download/385

Eccles, J. (1997). User-friendly science and mathematics: Can it interest girls and minorities in breaking through the middle school wall? In D. Johnson (Ed.), Minorities and girls in school: Effects on achievement and performance (pp. 65-104). Thousand Oaks, CA: Sage. 
Epstein, J. (1992). School and family partnerships. In M. Aikin (Ed.), Encyclopaedia of Educational Research (pp. 1110-1151). New York: MacMillan.

Ferry, N. M. (2006, June). Factors Influencing Career Choices of Adolescents and Young Adults in Rural Pennsylvania, Journal of Extension 44 (3). Retrieved on December 5, 2013 from http://www.joe.org/joe/2006june/rb7.php

Gesinde, S.A. (1986) Vocational Theories Applied to the Nigerian Cultural Background. In T. Ipaye (Ed), Educational and Vocational Guidance (pp. 207 - 221). Ile-Ife, Nigeria: University of Ife press.

Giachino, J.W. and Gallington, R.O. (1977). Course construction in industrial arts, vocational and technical education. Chicago: American Technical Society.

Gravetter, F. J and Wallnau, L. B. (2005). Essentials of statistics for behavioural science. New York: West Publishing Company.

Hall, C., Sullivan, S., Kauffman, P., Batts, D. \& Long, J. (2009). Are there gender differences in factors influencing career considerations? American Journal of Educational Studies, 2(1), 23-37. Retrieved on December 5, 2013 from http://www.amhighed.com/documents/journal/AJES_Vol2_Number1_Nov20 09.pdf.

Hairston, J. E. (2000). How Parents Influence African American Students' Decisions To Prepare For Vocational Teaching Careers. Journal of Career and Technical Education 16 (2), 5-15

Hines, M. S. (1997, March). Factors influencing persistence among African American

Upperclassmen in natural science and science related majors. Paper presented at the Annual Meeting of the American Education Research Association, Chicago, IL.

Haverman, R., \& Wolfe, B. (1995). The determinants of children's attainments: A review of methods and findings. Journal of Economic Literature, 33, 1829-1878.

Lee, C. L. (1984). An investigation of the psychosocial variables in the occupational aspirations and expectations of rural black and white adolescents: Implication for vocational education. Journal of Research and Development in Education, 17(3), 28-440.

Leong, F. T. L. (1995). Career development and vocational behaviour of racial and ethnic minorities. New Jersey: Lawrence Erlbaum Associates.

Miller, M.D. (1985) Principles and a philosophy for vocational education. Columbus: National Centre for Research in Vocational Education. Ohio State University. 
National Commission for College of Education (2008) Minimum Standards for NCE Teachers - Vocational and Technical, Abuja: National Commission for College of Education.

Okon S.E. (1986). The role of education in career and vocational development. In T. Ipaye (Ed), Educational and Vocational Guidance (pp. 75 - 92). IleIfe: University of Ife press.

Olayinka, M.S. (1983). Youth and career guidance. In A. Uba, (Ed), Introduction to counselling (pp. 125 - 137). Ile-Ife: University of Ife Press.

Otto, L. B. (1989). How to help your child choose a career. Florida: State Department of Education. (ERIC Document Reproduction Service No. ED $336506)$

Reynolds, C (2013) Factors affecting the choice of courses in college. Retrieved on December 15, 2013 from http://classroom.synonym.com/factors-affecting-choice-courses-college2817.html.

Sharf, R. S. (1992). Applying career development theory to counselling. USA: Brooks/Cole.

Splaver, S. (1977). Your personality and your career. New York, NY: Julian Messner.

Walton, G. M., \& Cohen, G. L. (2007). A question of belonging: Race, social fit, and achievement. Journal of Personality and Social Psychology, 92, 8296. 